\title{
INVESTIGATION OF ELECTROMAGNETIC FIELDS IN RESIDENTIAL AREAS
}

\author{
Dušan MEDVEĎ, Ondrej HIRKA \\ Department of Electric Power Engineering, Faculty of Electrical Engineering and Informatics, \\ Technical University of Košice, Mäsiarska 74, 04201 Košice, Slovak Republic, \\ Tel.: +421 55602 3555, E-mail: dusan.medved@tuke.sk
}

\begin{abstract}
This article is devoted to investigation of impact of electromagnetic fields around the electrical equipment used in a residential area and their impact on the human body. This paper was based on sets of measurements of magnetic induction $B$ with magnetometer and on computational simulations in ANSYS for particular appliances often used in household. The results from measurements and simulations led to setting out the recommendations for practical action in the form of elimination of harmful electromagnetic radiation.
\end{abstract}

Keywords: electromagnetic field, electromagnetic radiation, magnetic induction, teslameter

\section{INTRODUCTION}

Currently, there is a large development and increased number of electrical and power equipment, which are sources of electromagnetic radiation. Electromagnetic fields are all around us, whether in natural or artificial forms. The most fundamental and also the largest source of electromagnetic field is the Sun. Its non-ionizing radiation has a significant effect on the existence of life on Earth. The spectrum of the solar electromagnetic radiation has a wide range, which includes visible, ultraviolet, and infrared frequencies. In the industry, these fields are produced in the manufacture, distribution and consumption of AC electric power or as a side-effect of technological processes based on the passage of direct electrical current. The above sources generate electromagnetic radiation that have an adverse effect on a human body. Individual electromagnetic fields are biologically active throughout the whole range, which was proved experimentally as well as statistically [11].

The biological effects of electromagnetic fields vary and depend on several parameters [14]:

- the frequency range

- activity duration

- magnitude of field density

Furthermore, it obviously also depends on subjective parameters, the chemical-physical properties such as [14]:

- dimensions, weight and thickness of the layers (skin, fat layers, muscles)

- material of clothing

- water content

- mental and health condition of the human

Since the human body can be described as an environment that is highly variable and complex, since it comprises an aqueous electrolytic solution, the cell number of smaller structures such as cell membranes and different ones. Biological tissues contain a number of layers, which are different not only from the biological as well as dielectric properties, which results in changing of effect of the electromagnetic fields. In principle, we recognize two kinds of effects of electromagnetic fields: thermal and non-thermal [1].
Thermal effects depend mainly on the size in proportion to the frequency, i.e. that with the increasing frequency also increases the thermal effect of EMFs and are most severe in the microwave band. Given that the microwaves penetrate only to shallow depth due to the large decrease in the tissues, most at risk is the brain, the eyes and the male sex organs [6].

The non-thermal effects are related to long-term treatment with the weak fields. They are intended primarily to instantaneous amplitude of low-frequency radiation. Their effect increases with the repeated exposure to low intensity fields, particularly in the operation of the pulse of the fields in which the total energy is relatively small, but the instantaneous amplitude is large [6].

For this reason, the aim of this article is to present the way of determining the distribution of electromagnetic field around the home-used appliances. The determination of EMF was realized by measuring and also by simulation in multiphysical tool ANSYS. The results were compared and in the end of article, one can see the recommendation and awareness of using of bad-designed power devices.

\section{MEASUREMENTS OF MAGNETIC INDUCTION AROUND THE APPLIANCES}

The measurement of the magnetic induction was performed in home conditions (because of testing real conditions) close to appliances using of Gauss Meter / Teslameter Model 8030 (Fig. 1). The measuring frequency range of the alternating field is up to $50 \mathrm{kHz}$. An external 3D probe of type Z0A83-3208-10-T, with integrated Hall sensors, mediated the actual measurement.

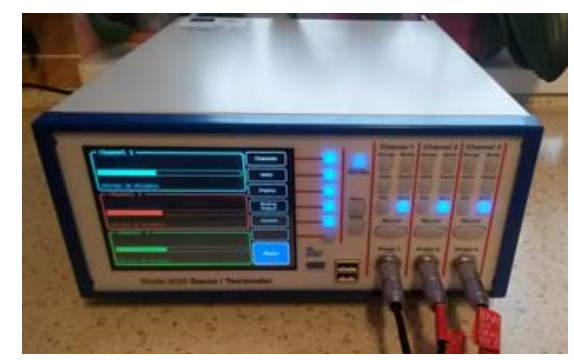

Fig. 1 Gauss Meter/Teslameter Model 8030 
This apparatus is a three-channel magnetometer, which is able to measure and display up to 7 different parameters. To measure it must be accompanied by a specialized probe that is of the sixth generation, which uses Hall effect phenomenon. The probe comprises of three probes, each being stored in one of the axes $x, y, z$. Before measuring, it was necessary to calibrate device using of zero-setting probe.

Sufficiently, to increase the accuracy of measurement, it was necessary to eliminate the factors affecting the measurement uncertainty. One of the main factors that affect the measurement and thus the measurement results were metal subjects. Therefore, as a basic worktop on which the appliance was placed measured appliance (microwave oven, hair dryer) was a wooden table.

The following Table 1 shows the measured power consumption of appliances:

Table 1 Power consumption of measured appliances

\begin{tabular}{ccc}
\hline \hline Appliance & Type & Input power $(\mathrm{W})$ \\
\hline Microwave oven & Electrolux EMS 2320X & 800 \\
Induction cooker & Baumatic BHI615 & $2 \times 2000,2 \times 1500$ \\
Hair dryer & ETA Colorino & 1800 \\
\hline \hline
\end{tabular}

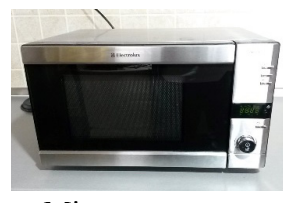

Microwave oven

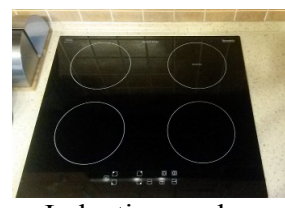

Induction cooker

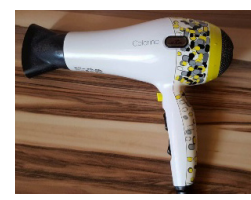

Hair dryer
Fig. 2 Illustrations of investigated sources of electromagnetic field commonly used in a household

\section{GEOMETRICAL MODELS}

Particular two-dimensional models represent the appliances and human that were modeled using ANSYS Mechanical APDL. Two-dimensional simplified models were chosen as the base for simulation for easier and faster computations. Particular appliances and human were modeled using the $2 \mathrm{D}$ areas. The outer area (air) was modeled as a rectangle of $2 \times 2,8 \mathrm{~m}$ with no influencing subjects (that could affect the results of electromagnetic field) (see Fig. 3). Through this model (appliance and human) there was created non-symmetrical logarithmic mesh (Fig. 4) because of respecting skin depth due to high frequencies.

The below Table 2 shows the material properties required for the simulation. These parameters represent the relative permeability and electrical resistivity of each material [2]. The value of the relative permeability was set according to blood flowing that was supposed to be higher due to erythrocytes (ferromagnetic material).

Table 2 Material properties

\begin{tabular}{|c|c|c|c|}
\hline No. & Material & $\begin{array}{c}\text { Relative permeability } \\
\mu\left[\mathrm{H} \cdot \mathrm{m}^{-1}\right]\end{array}$ & $\begin{array}{c}\text { Resistivity } \\
\rho[\Omega \cdot \mathrm{m}]\end{array}$ \\
\hline 1 & Air & 1,00005 & $1,3 \cdot 10^{16}$ \\
\hline 2 & Copper & 0,99994 & $1,68 \cdot 10^{-8}$ \\
\hline 3 & Skin & 20 & 1,66 \\
\hline
\end{tabular}

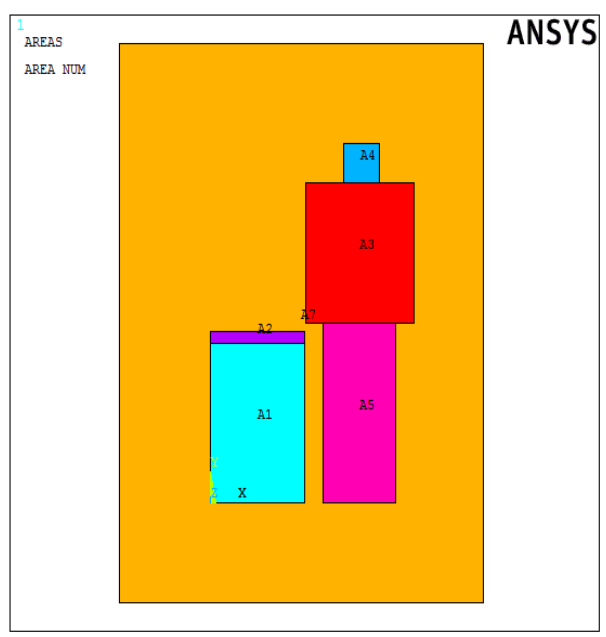

Fig. 3 The geometrical model of induction cooker and human (A1 - stand for induction cooker; A2 - induction cooker; A3 human torso; A4 - human head; A5 - human legs; A7 - air)

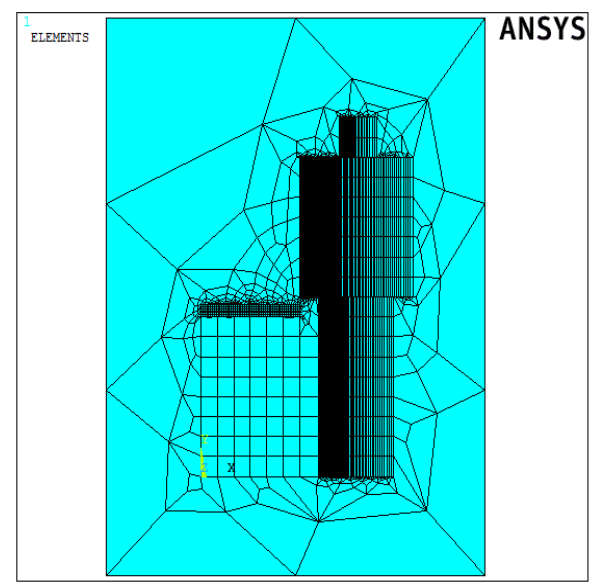

Fig. 4 The generated logarithmical mesh (due to skin-effect) of induction cooker and human

\section{RESULT COMPARISON OF PARTICULAR APPLIANCES}

According to simulation there was created the curve representing the characteristics of magnetic induction decreasing with an increasing distance from the source. On the graph (Fig. 5 to 7) one can see the allowable value of magnetic induction from the particular appliance.

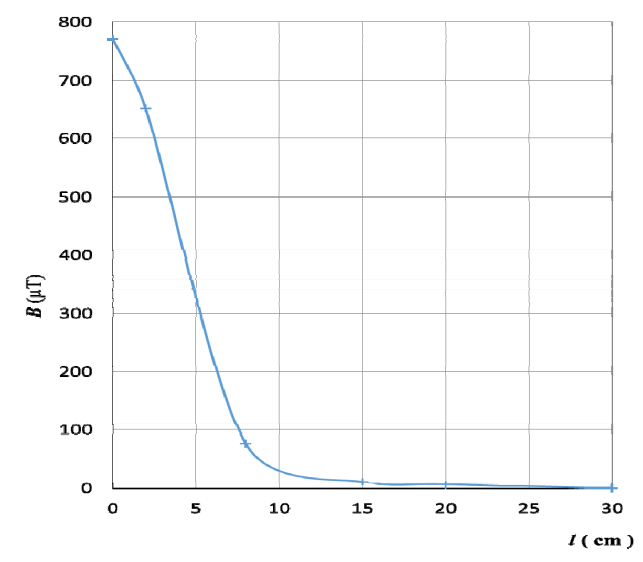

Fig. 5 Dependence of magnetic induction from a distance (microwave oven) 
Allowable value of magnetic induction according to standard [15] for the frequency $2,45 \mathrm{GHz}$, close to microwave oven is $0,2 \mu \mathrm{T}$.

Allowable value of magnetic induction according to standard [15] for the frequency range of induction cooker $20 \div 50 \mathrm{kHz}$, close to induction cooker is $6,25 \mu \mathrm{T}$.

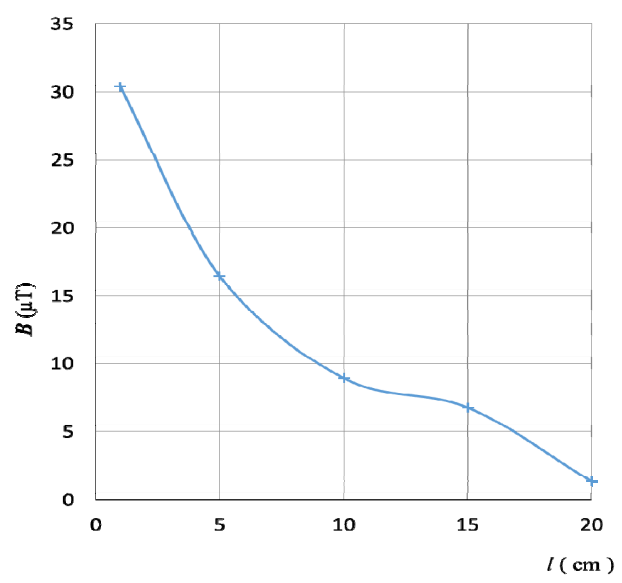

Fig. 6 Dependence of magnetic induction from a distance (induction cooker)

Allowable value of magnetic induction $B_{\text {allow }}$ at $f=50 \mathrm{~Hz}$, close to hair dryer could be calculated as it follows (according to standard [15]):

$$
B_{\text {allow }}=\frac{5}{f}=\frac{5}{50}=0,1 \mu \mathrm{T}
$$

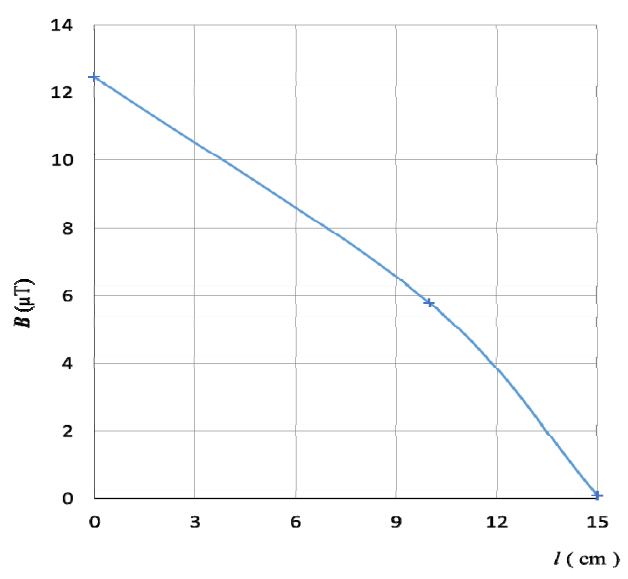

Fig. 7 Dependence of magnetic induction from a distance (hair dryer)

\section{ELECTROMAGNETIC FIELD DISTRIBUTION IN THE BODY INFLUENCED BY APPLIANCES}

The following figures (Fig. 8 (zoomed for better recognition of magnetic field absorption) and Fig. 9) show the distribution of magnetic induction $\boldsymbol{B}$ in the human body at different distances from the source of electromagnetic radiation. One can see the distribution of magnetic field lines around a person and induction cooker (Fig. 10) where the densely distribution of magnetic field lines represents the highest value of magnetic intensity $\boldsymbol{H}$, and thus the higher density of eddy currents. For this reason, the manufacturers of domestic appliances must take into account the appropriate shielding covers on appliances preventing human against the electromagnetic field of dangerous magnitudes.

\subsection{Microwave oven graphical results (close-up of a human torso)}

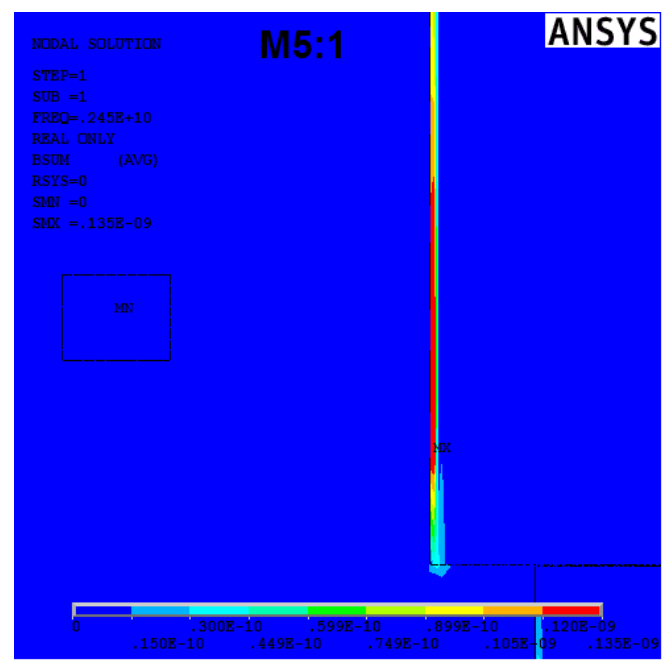

a)

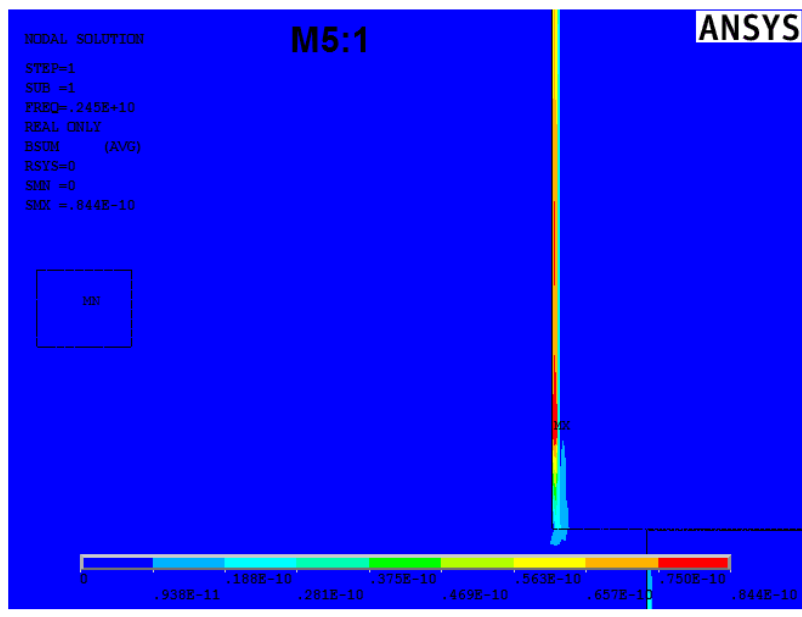

b)

Fig. 8 a) distribution of the magnetic induction in the person's torso at a distance of $0 \mathrm{~cm}$; b) distribution of the magnetic induction in the person's torso at a distance of $20 \mathrm{~cm}$

\subsection{Graphical results of the induction cooker}

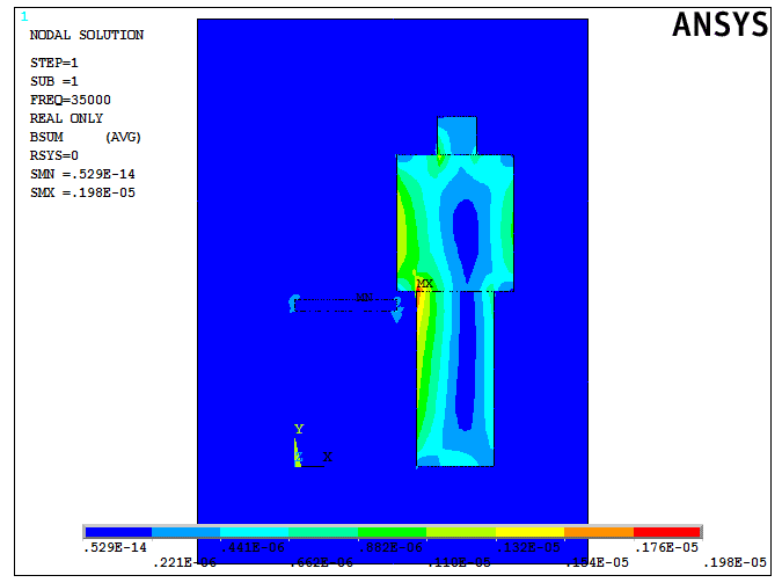

a) 


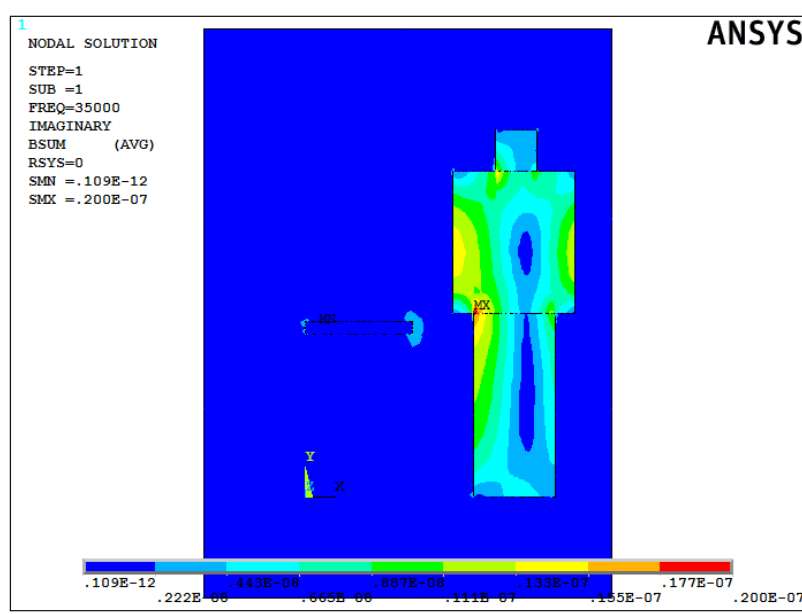

b)

Fig. 9 a) distribution of the magnetic induction in the person's torso at a distance of $0 \mathrm{~cm}$; b) distribution of the magnetic induction in the person's torso at a distance of $20 \mathrm{~cm}$

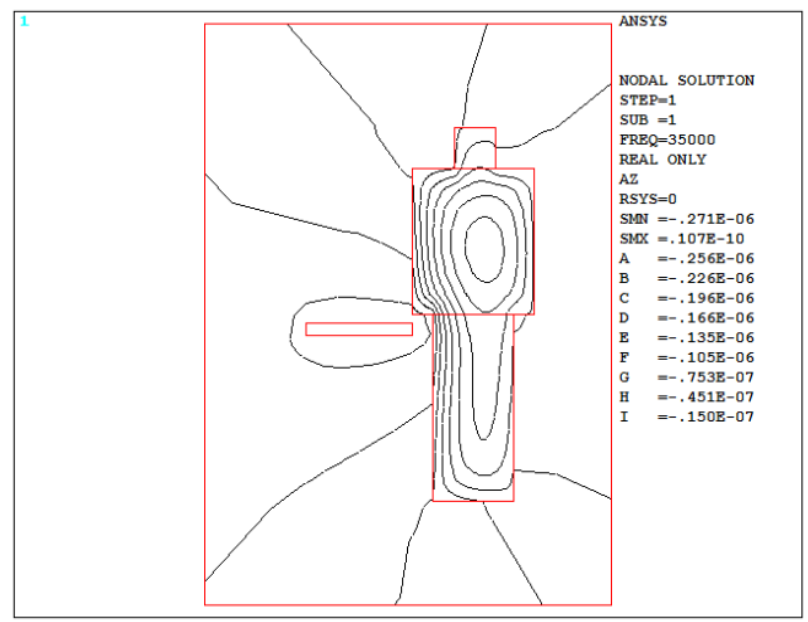

Fig. 10 Distribution of magnetic field lines around a person and induction cooker

\section{EVALUATION OF MEASURED RESULTS}

From the measured result as well as the simulation results, it indicates that the greatest value of the magnetic induction $\boldsymbol{B}$ reaches from the microwave oven. We can also observe that with increasing distance from the appliance, the value of magnetic induction decreases, thereby the effect of electromagnetic fields is decreased. When measuring the magnetic induction around the microwave oven, we found that allowed distance at which the magnetic induction is permitted, is value more than $30 \mathrm{~cm}$. At a distance of less than $30 \mathrm{~cm}$ the people would not linger near the appliance in operation, respectively. They should move away as soon as possible. According to the results of the simulation, it confirmed the theoretical assumptions [11] that the electromagnetic radiation in the microwave band penetrates only to shallow depth. When measuring $\boldsymbol{B}$ around the induction cooker it was possible to determine that a safe distance is more than $16 \mathrm{~cm}$ above the induction cooker. It is therefore necessary during the cooking use sufficiently long kitchen utensils made of non-metallic materials in order to avoid the adverse effects of electromagnetic fields on the human body. When measuring the $\boldsymbol{B}$ around the hair dryer, there was observed 830-times higher value of $\boldsymbol{B}$ than the permissible value, so the usage time of the appliance should be ensured minimal. In addition, the required minimum distance is $15 \mathrm{~cm}$ from the head for drying hairs to keep it within the permissible value of magnetic induction. All these values were compared with exposure action values for electric, magnetic and electromagnetic fields defined in the Health Ministry Decree no. 534/2007 Collection of Laws [15].

\section{CONCLUSIONS}

There are several ways to eliminate the adverse effects of electromagnetic fields on the human body. One of the basic ways resulted from the presented simulation as well as the measurement is the type of source (characterized by direct/harmonic/impulse current/voltage magnitude, its frequency) and the distance from the source. When a human is staying away from electrical appliances, the effects of electromagnetic fields becomes decreased inversely proportional to the square root of distance. Another way of eliminating the adverse effects of electromagnetic fields on the human body is the protection time, which means that the shorter time of electrical appliance using tends to weaker effect of influencing by electromagnetic field. There is still the possibility of the elimination of electromagnetic radiation by shielding (by additive conductive painted layer or by conductive cover, such as cloth) [9], [12], [16], [17].

We therefore propose to electrical appliances manufacturers to deal with the detailed research of electromagnetic fields distribution and materials utilized for electromagnetic fields absorbing such the permalloy or anti-magnetic foils, special coatings based on graphite. Another recommendation is to provide information on permissible times and distances when working with electrical appliances to avoid adverse effects on the human body and therefore it could be necessary to enact it in laws in Slovakia.

\section{ACKNOWLEDGMENTS}

This work was supported by the Ministry of Education, Science, Research and Sport of the Slovak Republic and the Slovak Academy of Sciences under the contract No. VEGA 1/0132/15.

\section{REFERENCES}

[1] CELENEC: Expozícia EMP vpásmu vysokých kmitočtù $(10 \mathrm{kHz}-300 \mathrm{GHz})$, Bruxelles, CELENEC, 1995, $44 \mathrm{p}$.

[2] HIRKA, O.: Assessment of the impact of electromagnetic fields in residual areas. Bachelor thesis. Košice: Faculty of Electrical Engineering and Informatics, Technical University of Košice, 2016.

[3] KANÁLIK, M. - KOLCUN, M.: The principle of actual short-circuit power determination in different nodes of the power, In: Elektroenergetika 2013: Proceedings of the $7^{\text {th }}$ International Scientific 
Symposium on Electrical Power Engineering: September 18-20, 2013, Stará Lesná, Slovak Republic, Košice: TU FEI, 2013, pp. 44-47, ISBN 978-80-553-1441-9.

[4] KOLLER, L. - NOVAK, B. - TEVAN, G.: Heating Effects of Short-Circuit Current Impulses on Contacts and Conductors-Part I. IEEE Transactions on Power Delivery, Jan. 2008, Vol. 23, Issue 1, pp. 221-227, ISSN 0885-8977, DOI: 10.1109/TPWRD.2007.905806.

[5] KOLLER, L. - NOVAK, B. - TEVAN, G.: Heating Effects of Short-Circuit Current Impulses on Contacts and Conductors-Part II. IEEE Transactions on Power Delivery, Jan. 2008, Vol. 23, Issue 1, pp. 228-232, ISSN 0885-8977, DOI: 10.1109/TPWRD.2007.905807.

[6] MAYER, D.: Aplikovaný elektromagnetizmus, Nakladatelství Kopp, České Budějovice 2012.

[7] MEDVEĎ, D. - KANÁLIK, M.: Riešenie usporiadania elektromagnetického pol'a vokoli elektrických silových vedení, In: Elektroenergetika, Vol. 8, No. 2, 2015, pp. 9-12, ISSN 1337-6756.

[8] MEDVEĎ, D. - HIRKA, O.: Impact of electromagnetic fields in residential areas, In: Elektroenergetika, Vol. 9, No. 2, 2016, pp. 13-16. ISSN 1337-6756.

[9] MEDVEĎ, D.: Modeling and Measuring of Electromagnetic Field around the $22 \mathrm{kV}$ Overhead Lines, In: Scientific Letters of Academic Society of Michal Baludansky, Vol. 4, No. 6A, 2016, pp. 6469, ISSN 1338-9432.

[10] MEDVEĎ, D. - MEŠTER, M. - SABOL, J.: Vplyv expozície elektromagnetického žiarenia na okolité elektroenergetické zariadenia vn/nn vo vonkajšom prostredi, In: Electrical Engineering and Informatics 7: Proceedings of the Faculty of Electrical Engineering and Informatics of the Technical University of Košice, Košice: TU, 2016, pp. 771776, ISBN 978-80-553-2599-6.

[11] MYSLÍK, J.: Elektromagnetické pole, základy teorie. Praha, BEN, 1998, 157 p.

[12] PAVLÍK, M. et al.: Measuring of Dependence of Shielding Effectiveness of Wet Materials on The Frequency of Electromagnetic Field in the High Frequency Range, In: Acta Electrotechnica et Informatica, Vol. 13, No. 3, 2013, pp. 12-16, ISSN 1335-8243.
[13] PAVLÍK, M. et al.: Meranie účinnosti tienenia elektromagnetického pol'a, In: EE Journal, Vol. 20, No. 3, 2014, pp. 16-18, ISSN 1335-2547.

[14] PRESMAN, A. S.: Electromagnetic field and life, Springer US: DOI: 10.1007/978-1-4757-0635-2.

[15] Vyhláška 534/2007 Zb. Ministerstva zdravotníctva Slovenskej republiky zo 16 . augusta 2007 o podrobnostiach o požiadavkách na zdroje elektromagnetického žiarenia a na limity expozície obyvatel'ov elektromagnetickému žiareniu v životnom prostredí.

[16] ZBOJOVSKÝ, J. - MÉSZÁROS, A. - KURIMSKÝ, P.: Modelling the high frequency electromagnetic field propagation through the polystyrene, In: Elektroenergetika, Košice: TU, 2015, pp. 556-559, ISBN 978-80-553-2187-5.

[17] ZBOJOVSKÝ, J. et al.: Výpočet účinnosti tienenia materiálov na základe simulácie elektromagnetického pol'a, In: Fyzikálne faktory prostredia, Vol. 4, No. 2, 2014, pp. 114-117, ISSN 1338-3922.

Received March 18, 2017, accepted August 8, 2017

\section{BIOGRAPHIES}

Dušan Medved' was born on 14.9.1979. In 2003 he graduated (MSc) with distinction at the Department of Electrical Power Engineering of the Faculty of Electrical Engineering and Informatics at Technical University of Košice. He defended his $\mathrm{PhD}$ in the field of electrical heating processes in 2008; his thesis title was "Heating of ferromagnetic materials up to Curie temperature by induction method". Since 2006 he worked as a senior scientist and since 2008 as an assistant professor at Department of Electrical Power Engineering. His scientific research is focusing on mathematical modeling of electromagnetic and thermal fields. In addition, he also investigates questions related with the computer modeling of faults in electric power systems.

Ondrej Hirka was born on 20.8.1993. In 2016 he graduated $(\mathrm{BSc})$ at the Department of Electrical Power Engineering of the Faculty of Electrical Engineering and Informatics at Technical University of Košice. He defended his B.Sc. in the field of numerical modeling of electromagnetic fields in 2016; his thesis title was "Assessment of impact of electromagnetic fields in residential areas". Since 2016 he is an MSc student of study program Electrical Power Engineering. 